den, die sich einen ersten Überblick verschaffen möchten, als auch jenen, die sich zu speziellen Themen vertieft informieren wollen. Dies gilt gleichermaßen für Leser, die sich im Kontext von WTO-Beitrittsverhandlungen als auch unabhängig hiervon mit den angesprochenen Themen befassen möchten.

Martina Franke, Halle/Saale

Ademola Abass (ed.)

\title{
Protecting Human Security in Africa
}

Oxford University Press Oxford, 2010, pp. 397; 72,00 £, ISBN 978-0-19-957898-6

\begin{abstract}
"Sicherheit" definieren zu wollen erinnert an die berühmte Pilatus-Frage ("Was ist Wahrheit?"). Trotzdem gaben die Völker der Vereinten Nationen 1945 ihrem schlagkräftigsten Organ den Namen "Sicherheitsrat" mit dem Auftrag, in ihrem Namen zu wachen über den Weltfrieden und die internationale Sicherheit. Gemeint waren damit in erster Linie die Beziehungen zwischen den Staaten. Deren Binnen-Verhältnisse, ebenfalls in der UN-Charta angedacht in der Entschlossenheit, "...den sozialen Fortschritt und einen besseren Lebensstandard in größerer Freiheit zu fördern", gerieten auf die internationale Agenda erst mit dem völkerrechtlichen Siegeszug der Menschenrechte und der Überwindung der Ost-West-Konfrontation. Sie gab den Weg frei, nach dem Wettrüsten auch andere unhaltbare Zustände und Vorgänge, namentlich eben auch solche innerhalb der Staaten, international als Sicherheitsrisiken zu begreifen.

Diesen Gedanken übernahm das UN-Development Programme in seinen Human Development Report 1994: Anders als zuvor in den Zeiten ideologischer Instrumentalisierung der Entwicklungs-"hilfe" sollten nicht mehr die Staaten, geschweige denn deren Regierungen, im Focus stehen, sondern die Menschen mit ihrem Bedürfnis nach Sicherheit, zuvörderst ihrer Person, aber auch ihrer Lebensumstände. Das war die Geburtsstunde des Konzepts "Human Security" (eingedeutscht "menschliche" Sicherheit, "persönliche" hätte es womöglich eher getroffen). Nicht ohne Pathos, aber sehr eindrücklich formulierte der HDR 1994: "Human security is a child, who did not die, a disease that did not spread, a job, that was not cut, an ethnic tension that did not explode in violence, a dissident, who was not silenced". Human security, anfänglich in den Augen mancher Kritiker nicht mehr als eine überflüssige Erfindung ("Wozu Human Security, wo wir doch die Human Rights haben") ist inzwischen ein fester Topos im internationalen politischen Diskurs geworden, UN- wie auch EU-weit. ${ }^{1}$
\end{abstract}

1 Für die UN z.B. nunmehr Generalversammlung, A/66/L.55/Rev. 1 v. 06. September 2012. Für die EU insbesondere Human Security Study Group, A European Way of Security: The Madrid Report of the Human Security Study Group comprising a Proposal and Background Report, Madrid 2007, http:// www.1se.ac.uk/Depts/global/PDFs/Madrid\%20Report\%20Final\%20for\%20distribution.pdfK; kritisch z. B. Janne Haaland Matlary, Much ado about little: the EU and human security, International Affairs 84: 1 (2008) 131-143. 
Was von alledem in Afrika realiter ankommt - oder umgekehrt: Wie weit mitunter die afrikanische Realität davon entfernt ist, das beleuchtet das 13 köpfige Autorenteam des vorliegenden Sammelbandes engagiert, kompetent, materialreich und umfassend: Erfrischend wird hier unbefangen Tacheles geschrieben von (meist) Afrikanern für Afrikaner folglich mit kritischen Tönen auch und manchmal gerade an die eigene Adresse. Schon im Vorwort lässt es Herausgeber Ademola Abass, Professor für (insbesondere Friedens-) Völkerrecht an der Brunel University, West London, an deutlichen Worten sogar auf dem diplomatisch-sensiblen Terrain eines klassischen Tabu-Themas nicht fehlen: "...The international law principle of non-intervention in internal affairs of States, which many members of the...OAU hijacked to shield their reigns of terror from international scrutiny, has now been replaced by a policy of 'no indifference' by the African Union..."

Der ausgesprochen sorgfältig edierte Sammelband ist opulent nutzerfreundlich ausgestattet mit einem ausführlichen Abkürzungs- und Autorenverzeichnis, einem Zitat-Register sämtlicher in Bezug genommener einschlägiger Judikate und völkerrechtlicher Quellentexte global, regional und national sowie einer umfangreichen Auswahlbibliographie und schlussendlich einem fast lexikalisch detaillierten Sachregister auf 25 Seiten.

Inhaltlich trifft man auf eine klare Gliederung: Im gleichsam vor die Klammer gezogenen Anfangskapitel ("An Introduction to Protecting Human Security in Africa") macht Herausgeber Ademola Abass vertraut mit Historie und politischen Dimensionen des Human-SecurityKonzepts, verortet das Thema im aktuellen Diskurs über Human Rights und Human Development und lässt anschließend in gedrängter Form Revue passieren, was das Publikum zu erwarten hat in den folgenden drei Abschnitten, die insgesamt 14 Kapitel umfassen.

Der Erste Abschnitt, statt sich in der bereits quantitativ imponierenden Komplexität der Materie zu verlieren, lässt es in weiser Beschränkung bewenden mit einer überschaubaren Auswahl dafür aber umso schwerer wiegender Risikofaktoren ("Of certain Threats to Human Security in Africa"). Es sind ihrer neun: Beginnend mit Ernährung (Opeoluwa Badaru: "Food Security in Africa"), Umwelt (Ilias Bantekas: "Environmental Security in Africa"), Kleinwaffenboom (Kwesi Aning: "Understanding the Nexus between Human Security and Small Arms in Africa: The case of Ghana"), gefolgt von Ausbeutung (Ben Chigara: "The ILO and 'Human Security' of Sub-Saharan African Labour"), Ressourcenbewirtschaftung (Abiodun Alao: "Natural Resource Management and Human Security in Africa"), Piraterie (Efthymios Papastavridis: "Piracy off Somalia: The 'Emperors and the Thieves of the Oceans' in the 21st Century") bis zu Flucht und Vertreibung (Maria O'Sullivan: "Human Security and the Protection of Refugees in Africa"), Frauenrechten (Manisuli Ssenyonjo: "Human Rights of Women in Africa: A Prerequisite for Human Security") - mit 40 Seiten umfangreichster Beitrag - und last not least Korruption (Ebenezer Durojaye: "Corruption as a Threat to Human Security in Africa"). Zu den Beiträgen dieses Abschnitts, die sich qualitativ in nichts nachstehen, nur ein paar vereinzelte Bemerkungen:

Die Piraterie am Horn von Afrika ist mittlerweile etwas abgeflaut, - ob wegen der Urteile der 3. Großen Strafkammer des Hamburger Landgerichts im Piratenprozess 2012, sei dahingestellt. Zweifel bleiben, ob die der Piraterie zugrunde liegenden Faktoren wirklich erst in der 
fremden räuberischen Überfischung der wehrlos ungeschützten Fanggründe vor Somalias Küste zu suchen sind, oder zumindest auch im schon vor Jahrzehnten längst hausgemachten Kollaps der somalischen Staatlichkeit liegen.

Kaum ein Gedankenaustausch zur Entwicklungszusammenarbeit ohne das Stichwort Korruption. Aber muss man es so wortmächtig angehen lassen wie hier: "One of the greatest challenges facing African countries today is the issue of corruption". Die Antwort nach der Lektüre: Ja. Leider. Wie sich nicht nur im Großen an den hier angeführten Beispielen der gefälschten kenianischen Präsidentenwahlen 2007, dem unglaublichen Niedergang Zimbabwes und der partiellen Unregierbarkeit Nigerias belegen lässt, kann für die human security auch im persönlichen Alltag Korruption ganz direkt (sogar lebens-)gefährlich werden: Wenn korrupte Sicherheitsorgane Kriminalitätsopfer ignorieren, gar selber Täter werden, wenn ausgepowerte Gesundheitssysteme kollabieren oder längst korruptionsmarode Infrastrukturen Todesopfer fordern. Zu Korruptionsfaktoren können neben Geldgier übrigens auch ethnische und religiöse Intoleranz werden.

Der Zweite Abschnitt behandelt die institutionellen Bezüge des Themas ("Regional Institutions and Mechanisms"). Auch hier weist eingangs wieder Ademola Abass den Weg ("African Peace and Security Architecture and the Protection of Human Security"). In den restlichen drei Kapiteln geht es um die Einbettung in das Afrikanische MenschenrechtsSchutzsystem mit den Beiträgen von Gino J Naldi: ("The Role of the Human and Peoples' Rights Section of the African Court of Justice and Human Rights"), Obiora Chinedu Okafor ("The African Commission on Human and Peoples' Rights as a Collective Human Security Resource: Promise, Performance and Prospects") und Rachel Murray ("The Role of NGOs and Civil Society in Advancing Human Security in Africa").

Nur ein Zwischenruf hierzu: Ein Konzept wie Human Security lässt sich in unseren Zeitläuften nicht fruchtbar machen geschweige denn umsetzen ohne Mitwirkung von NGO's und anderen zivilgesellschaftlichen Akteuren. Man erfährt allerdings über das Engagement von NGO's und anderen zivilgesellschaftlichen Akteuren speziell auf dem Gebiet der Human Security, für die sich inzwischen ebenfalls ein institutioneller Rahmen etabliert hat, etwa seit 2001 die Commission on Human Security (CHS), nichts. Stattdessen geht es um die Zusammenarbeit mit der African Commission on Human and Peoples' Rights als einer etablierten Institution des afrikanischen Menschenrechtssystems, nicht anders übrigens, als zuvor bei Gino J Naldi mit Bezug auf den ACHPR. Beiden Schilderungen merkt man an: Das ist der feste Boden, den man souverän beherrscht, den man aber auch nicht gern verlässt. Auch dies vielleicht bezeichnend dafür, dass das Konzept der Human Security gegenüber den in Jahrzehnten festgefügten Strukturen der Menschenrechtsysteme bisweilen noch um seine profunde Akzeptanz ringen muss. ${ }^{2}$

2 Dazu z. B. schon Wolfgang Benedek/Matthias C.Kettemann, Menschliche Sicherheit und Menschenrechte, in: Cornelia Ulbert/Sascha Werthes (Hrsg.), Menschliche Sicherheit: Globale Herausforderungen und regionale Perspektiven, Baden-Baden 2008, S. 94 ff. und Franziska Senze, Der Einfluss des Human-Security-Konzeptes auf die Menschenrechte, Münster 2009. 
Mit dem - einzigen - Beitrag im Dritten Abschnitt ("Conclusion") meldet sich abschließend noch einmal Ademola Abass zu Wort ("The Future of Human Security in Africa"). Nach einer Zusammenfassung der wesentlichen Ergebnisse, die anschaulich demonstriert, was für ein Herzensanliegen ihm das Thema des Buches ist, mutet sein Ausblick, anknüpfend an den wohltuenden Klartext des Vorworts, leicht besorgt, aber doch vergleichsweise versöhnlich an:

"Unlike some other global concepts, human security did not arrive with its own toolkit, so that we can unpack the box and get to work immediately. Yet, we did not simply happen upon it, as with penicillin, when looking for something else. In a sense, human security has been with us from the start of humanity. The problem is that humankind's original vision of security was clouded by a collective preoccupation with nuclear security. Human security is the new way of rethinking our survival."

Man kann es drehen und wenden, wie man will: Dem ist nichts hinzuzufügen.

Karl-Andreas Hernekamp, Hamburg 